\title{
Somatic Effects of Ethyl Methane Sulphonate on White Seeded Sesame (Sesamum indicum. L) Varieties
}

\author{
V. Sandhiya ${ }^{1}$, C. Parameswari ${ }^{2}$, M. Kumar ${ }^{1}$, C. Vanniarajan ${ }^{2}$, \\ N. Kumaravadivel ${ }^{3}$, N. Sakthivel ${ }^{4}$ and Anand M. Badigannavar ${ }^{5}$
}

${ }^{1}$ Centre for Plant Breeding and Genetics, Tamil Nadu Agricultural University, Coimbatore, India

${ }^{2}$ Department of Plant Breeding and Genetics, Agricultural College and Research Institute, TNAU, Madurai, India

${ }^{3}$ Department of Plant Molecular Biology and Bioinformatics, CPMB, TNAU, Coimbatore, India

${ }^{4}$ Department of Agronomy, TNAU, Coimbatore, India

${ }^{5}$ NABTD, Bhabha Atomic Research Centre, Mumbai, India

*Corresponding author

\section{A B S T R A C T}

\section{Keywords}

EMS, White seeded sesame, Mutation and Somatic effect

Article Info

Accepted:

18 May 2020

Available Online:

10 June 2020

\begin{abstract}
Induced mutations not only alter the plant genome but also affect the cellular component which leads to changes in seed germination to maturity traits. The aim of the present study was to investigate the somatic effect of chemical mutagen Ethyl Methane Sulphonate (EMS) on seed germination, shoot length, root length, plant photosynthetic pigments and nine yield attributing traits of two white seeded sesame varieties. Dose dependent negative linear effect was observed in seed germination, shoot and root length, plant pigments and some biometrical traits. Number of branches per plant, number of capsules in primary branch and number of capsules in secondary branch showed nonlinear effect on EMS. Based on germination, SVPR 1 was found to be more sensitive to EMS than VRI 3 but for seedling traits reverse case was observed. The highest mean significant yield was observed for SVPR 1 than VRI 3.
\end{abstract}

\section{Introduction}

Sesame has been proposed as the oldest oil seed crop in the world (Joshi, 1961). Sesame is cultivated in all the tropical and subtropical countries mainly in hotter and drier parts of Africa, India and Mediterranean region. Origin of sesame is not clearly understood and even the notable botanists, De Candolle,
Vavilov and Watt suggested the different origins for sesame (Nayar and Mehra, 2009).

For a simpler understanding of sesame origin, it is suggested that Africa might be the possible primary centre because of the presence of large number of wild relatives and India as a secondary centre (Kochhar, 2011). Sesame belongs to the small family of 
Pedaliaceae and the genussesamum has 34 species. The chromosome number of most of the wild species was not known till now. The chromosome number of sesame species varies from $2 \mathrm{n}=26,32$ and 64 (Nayar and Mehra, 2009). However, sesame has long evolutionary history, the crop still has undesirable traits like indeterminate flowering, low harvest index, uneven capsule ripening and shattering capsules which makes to the crop un suitable for modernized agricultural practices.

Plant breeders still focus on enhancing variability for desirable trait development. Mutation breeding offers the scope of new trait discovery. Induced mutation by some physical and chemical mutagenic agent not only alters the nucleus and cytoplasmic genome of the cells but also creates damages in all cellular components and disturbs the cell cycle. These effects can harm the cell metabolism and impair the growth and development of $\mathrm{M}_{1}$ plants. These somatic effects are manifested by a delay in seed germination, reduction of plant emergence, growth reduction, appearance of chlorophyll defects, reduction of fertility and plant survival. Optimum plant population in $\mathrm{M}_{1}$ is essential maintain to increase the frequency of viable mutants in $\mathbf{M}_{2}$ generation (SpencerLopes et al., 2018). Maintenance optimum of $\mathrm{M}_{1}$ population depends on the effect of mutagen on cellular components. The present investigation revealed the somatic effect of chemical mutagen Ethyl Methane Sulphonate (EMS) on seed germination, seedling vigour, chlorophyll content, injury and lethality of white seeded sesame varieties.

\section{Materials and Methods}

The present experiment was conducted at Agricultural College and Research Institute, Madurai. SVPR 1 and VRI 3, two white seeded varieties of sesame developed in
Tamil Nadu Agri. University were used for this study. One gram of seeds of each variety was treated with seven different concentrations of EMS viz., $0.2 \%, 0.4 \%, 0.6$ $\%, 0.8 \%, 1 \%, 1.2 \%$ and $1.4 \%$ and sown in Pro trays with two replications and maintained under shade net house. Seed germination was counted at 6 DAS and germination percentage (Scott et al., 1984) was calculated for all the seven EMS concentrations. Shoot length and root length was measured at 15 DAS from ten randomly selected seedlings. LD 50 dose calculated from seven EMS concentrations was nearer to $0.4 \%$ for both the varieties. So, $0.4 \%$ percent was fixed as optimum dose for white seeded sesame. So, seeds of both varieties were treated with two doses of EMS above and below LD 50 viz., $0.2 \%, 0.3 \%, 0.4 \%, 0.5 \%$ and $0.6 \%$ EMS and raised in the field condition. Leaf photosynthetic pigments viz., chlorophyll a, chlorophyll $\mathrm{b}$, total chlorophyll and carotenoid contents were estimated from 15 days old seedlings of all the ten treatments by Acetone method (Yoshida et al., 1971). Biometrical traits viz., plant height, hight of first capsule, number of branches, number of capsules in primary branch, number of capsules in secondary branch, total no of capsules, capsule length, 1000 seed weight and single plant yield was observed in 10 randomly selected plants of each doses in both the varieties.

\section{Results and Discussion}

Mean value of germination percentage, shoot length and root length calculated for seven doses of EMS treated seeds and control seeds of both the varieties are depicted in table 1 . These traits were considerably affected by EMS treatment. Germination was completely arrested after $0.6 \%$ EMS concentration in both the varieties. Germination percentage of SVPR 1 ranged from 25.00 per cent $(0.6 \%$ EMS) to 83.33 per cent (0.2\% EMS) in EMS 
treated samples. In case of VRI 3, it varies from 37.50 per cent ( $0.6 \%$ EMS) to 97.22 per cent $(0.2 \%$ EMS). While comparing SVPR 1 with VRI 3, the mean germination percentage of VRI 3 treatments was $6.25 \%$ higher than SVPR 1.

This suggests that EMS has an inhibitory effect on germination in both the varieties but SVPR 1 was slightly more sensitive to EMS than VRI 3 variety. Shoot length and root length of control was $10.37 \mathrm{~cm}$ and $8.66 \mathrm{~cm}$ for SVPR 1 and $7.88 \mathrm{~cm}$ and $6.74 \mathrm{~cm}$ for VRI 3.

Shoot length and root length of all the doses were lower than their control in both the varieties. Shoot length and root length of SVPR 1 ranged from $3.35 \mathrm{~cm}(1.4 \%$ EMS $)$ to $8.65 \mathrm{~cm}(0.2 \%$ EMS $)$ and $2.47 \mathrm{~cm}(1.4 \%$ EMS) to $6.77 \mathrm{~cm}(0.2 \%$ EMS), respectively in EMS treated samples. In case of VRI 3, this varied from $3.17 \mathrm{~cm}(1.4 \%$ EMS $)$ to $7.21 \mathrm{~cm}$ $(0.2 \%$ EMS $)$ and $1.99 \mathrm{~cm}(1.4 \%$ EMS $)$ to $6.18 \mathrm{~cm}(0.2 \%$ EMS $)$, respectively.

Shoot length and root length of control and EMS treated samples of SVPR 1 was relatively higher than VRI 3. From the shade net house study, using seven different EMS concentrations, it was found that germination percentage, shoot length and root length of both the varieties decreased with increased concentration of EMS.

These results were on par with the results of Kumar and Pandey. (2018), Kumari et al., (2016) and Ariraman et al., (2014). Estimation of photosynthetic pigments for five EMS concentrations are given in Table 2. Photosynthetic pigments showed slight variations in control and treated individuals. Chlorophyll a, b, total chlorophyll and carotenoid content were found to be higher in control than in the treated individuals of both the varieties.
Chlorophyll $\mathrm{a}$ and $\mathrm{b}$ content of SVPR 1 ranged from $15.742 \mathrm{mg} / \mathrm{gFW}(0.6 \%)$ to $19.114 \mathrm{mg} / \mathrm{gFW}(0.2 \%)$ and $5.841 \mathrm{mg} / \mathrm{gFW}$ $(0.6 \%)$ to $7.323 \mathrm{mg} / \mathrm{gFW} \quad(0.2 \%)$, respectively in EMS treated samples. Total chlorophyll and carotenoid content were from $21.583 \mathrm{mg} / \mathrm{gFW}(0.6 \%)$ to $26.437 \mathrm{mg} / \mathrm{gFW}$ $(0.2 \%)$ and $0.014 \mathrm{mg} / \mathrm{gFW}(0.6 \%)$ to 0.017 $\mathrm{mg} / \mathrm{gFW}(0.2 \%)$, respectively.

In case of VRI 3chlorophyll a, b and total chlorophyll contents were varied from 19.319 $\mathrm{mg} / \mathrm{gFW}(0.6 \%)$ to $25.306 \mathrm{mg} / \mathrm{gFW}(0.2 \%)$, $14.312 \mathrm{mg} / \mathrm{gFW}(0.6 \%)$ to $18.408 \mathrm{mg} / \mathrm{gFW}$ $(0.2 \%)$ and $5.007 \mathrm{mg} / \mathrm{gFW}(0.6 \%)$ to 6.905 $\mathrm{mg} / \mathrm{gFW} \quad(0.2 \%)$, respectively. The carotenoid content ranged from 0.014 $\mathrm{mg} / \mathrm{gFW}(0.6 \%)$ to $0.016 \mathrm{mg} / \mathrm{gFW}(0.2 \%)$ in treated samples of VRI 3.

An EMS concentration dependent decrease in photosynthetic pigments was observed in all the treatments. Increase in EMS concentration resulted in increase the inhibition of photosynthetic pigments. Similar results were observed by Kumar et al., (2018). Mean value for nine biometrical traits are presented in Table 3 and 4 for the varieties SVPR 1 and VRI 3, respectively.

Plant height ranged from $69.6 \mathrm{~cm}(0.6 \%)$ to $89.4 \mathrm{~cm}(0.2 \%)$ and $93.8 \mathrm{~cm}(0.2 \%)$ to 102.6 $\mathrm{cm}(0.2 \%)$ and height of first capsule varied from $29.6 \mathrm{~cm}(0.6 \%)$ to $44.6 \mathrm{~cm}(0.2 \%)$ and $37.8 \mathrm{~cm}(0.4 \%)$ for SVPR 1 and VRI 3, respectively.

Mean range of single plant yield varied from $7.72 \mathrm{~g}(0.6 \%)$ to $13.13 \mathrm{~g}(0.2 \%)$ and from $2.54 \mathrm{~g}(0.6 \%)$ to $11.96 \mathrm{~g}(0.2 \%)$ for SVPR 1 and VRI 3, respectively. In case of SVPR 1, the traits viz.,plant height, height of first capsule, capsule length and 1000 seed weight and single plant yield were decreased by increased concentrations of EMS treatment. 
Table.1 Effect of EMS on seed germination, shoot length and root length

\begin{tabular}{|c|c|c|c|c|c|c|}
\hline $\begin{array}{c}\text { Treatments } \\
\text { EMS concentration } \\
(\mathbf{\%})\end{array}$ & \multicolumn{2}{|c|}{$\begin{array}{c}\text { Germination } \\
\text { percentage }\end{array}$} & \multicolumn{2}{|c|}{ Shoot length (cm) } & \multicolumn{2}{c|}{ Root length (cm) } \\
\cline { 2 - 7 } & SVPR 1 & VRI 3 & SVPR 1 & VRI 3 & SVPR 1 & VRI 3 \\
\hline $\mathbf{0 . 0}(\mathbf{C o n t r o l )}$ & 100.00 & 100.00 & 10.37 & 7.88 & 8.66 & 6.74 \\
\hline $\mathbf{0 . 2}$ & 83.33 & 97.22 & 8.65 & 7.21 & 6.77 & 6.18 \\
\hline $\mathbf{0 . 4}$ & 43.75 & 66.67 & 8.11 & 6.45 & 5.14 & 4.81 \\
\hline $\mathbf{0 . 6}$ & 25.00 & 37.50 & 7.55 & 6.13 & 4.88 & 5.03 \\
\hline $\mathbf{0 . 8}$ & 0.00 & 0.00 & 6.84 & 5.44 & 4.21 & 4.65 \\
\hline $\mathbf{1}$ & 0.00 & 0.00 & 5.34 & 4.68 & 3.54 & 3.15 \\
\hline $\mathbf{1 . 2}$ & 0.00 & 0.00 & 4.87 & 4.24 & 3.17 & 2.88 \\
\hline $\mathbf{1 . 4}$ & 0.00 & 0.00 & 3.35 & 3.17 & 2.47 & 1.99 \\
\hline Mean & 21.73 & 28.77 & 6.38 & 5.33 & 4.31 & 4.09 \\
\hline SD & 32.09 & 39.81 & 1.92 & 1.39 & 1.43 & 1.46 \\
\hline SE & 12.13 & 15.05 & 0.72 & 0.52 & 0.54 & 0.55 \\
\hline
\end{tabular}

Table.2 Effect of EMS on plant photosynthetic pigments

\begin{tabular}{|c|c|c|c|c|c|c|c|c|}
\hline $\begin{array}{c}\text { Treatments } \\
\text { EMS } \\
\begin{array}{c}\text { concentration } \\
(\boldsymbol{\%})\end{array}\end{array}$ & \multicolumn{2}{|c|}{ Chlorophyll a } & \multicolumn{2}{|c|}{ Chlorophyll b } & \multicolumn{2}{c|}{ Total chlorophyll } & \multicolumn{2}{c|}{ Carotenoid } \\
\hline SVPR 1 & VRI 3 & SVPR 1 & VRI 3 & SVPR 1 & VRI 3 & SVPR 1 & VRI 3 \\
\hline $\mathbf{0 . 0}(\mathbf{C o n}$ Strol) & 19.643 & 22.893 & 7.396 & 8.438 & 27.033 & 31.323 & 0.018 & 0.019 \\
\hline $\mathbf{0 . 2}$ & 19.114 & 18.408 & 7.323 & 6.905 & 26.437 & 25.306 & 0.017 & 0.016 \\
\hline $\mathbf{0 . 3}$ & 18.944 & 17.749 & 7.203 & 6.679 & 26.140 & 24.422 & 0.020 & 0.017 \\
\hline $\mathbf{0 . 4}$ & 16.960 & 16.778 & 6.115 & 6.123 & 23.070 & 22.901 & 0.016 & 0.016 \\
\hline $\mathbf{0 . 5}$ & 16.217 & 14.398 & 6.007 & 5.944 & 22.224 & 20.342 & 0.014 & 0.015 \\
\hline $\mathbf{0 . 6}$ & 15.742 & 14.312 & 5.841 & 5.007 & 21.583 & 19.319 & 0.014 & 0.014 \\
\hline Mean & 17.396 & 16.329 & 6.498 & 6.132 & 23.891 & 22.458 & 0.016 & 0.016 \\
\hline SD & 1.554 & 1.893 & 0.706 & 0.741 & 2.253 & 2.573 & 0.002 & 0.001 \\
\hline SE & 0.695 & 0.846 & 0.315 & 0.331 & 1.008 & 1.151 & 0.001 & 0.000 \\
\hline
\end{tabular}


Table.3 Effect of EMS of biometrical traits of SVPR 1

\begin{tabular}{|c|c|c|c|c|c|c|c|c|c|}
\hline $\begin{array}{c}\text { Treatments } \\
\text { EMS } \\
\text { concentration } \\
(\%)\end{array}$ & $\begin{array}{c}\text { Plant } \\
\text { height }\end{array}$ & $\begin{array}{l}\text { Height } \\
\text { of first } \\
\text { capsule }\end{array}$ & $\begin{array}{c}\text { Number } \\
\text { of } \\
\text { branches }\end{array}$ & $\begin{array}{l}\text { Number of capsules in } \\
\text { primary branches }\end{array}$ & $\begin{array}{l}\text { Number of } \\
\text { capsules in } \\
\text { secondary } \\
\text { branches }\end{array}$ & $\begin{array}{c}\text { Total } \\
\text { capsules }\end{array}$ & $\begin{array}{l}\text { Capsule } \\
\text { length }\end{array}$ & $\begin{array}{c}1000 \\
\text { seed } \\
\text { weight }\end{array}$ & $\begin{array}{l}\text { Single } \\
\text { plant } \\
\text { yield }\end{array}$ \\
\hline 0.0 Control & 93.4 & 48.8 & 2.8 & 19.6 & 14.8 & 34.4 & 2.48 & 3.61 & 8.86 \\
\hline 0.2 & 89.4 & 44.6 & 2.4 & 35 & 8.9 & 43.9 & 2.66 & 3.45 & 13.13 \\
\hline 0.3 & 86 & 35.4 & 3.2 & 27.6 & 14.2 & 41.8 & 2.62 & 3.33 & 11.41 \\
\hline 0.4 & 81.8 & 32.8 & 4 & 27.6 & 14.2 & 41.8 & 2.62 & 3.31 & 11.31 \\
\hline 0.5 & 72.2 & 31.4 & 2.6 & 17.2 & 15.8 & 38 & 2.5 & 3.25 & 8.89 \\
\hline 0.6 & 69.6 & 29.6 & 3 & 19 & 7.2 & 42.2 & 2.1 & 3.19 & 7.72 \\
\hline Mean & 79.8 & 34.76 & 3.04 & 25.28 & 12.06 & 41.54 & 2.5 & 3.306 & 10.492 \\
\hline SD & 8.61 & 5.89 & 0.62 & 7.25 & 3.77 & 2.16 & 0.23 & 0.10 & 2.16 \\
\hline SE & 3.85 & 2.64 & 0.28 & 3.24 & 1.68 & 0.97 & 0.10 & 0.04 & 0.97 \\
\hline
\end{tabular}

Table.4 Effect of EMS of biometrical trait of VRI 3

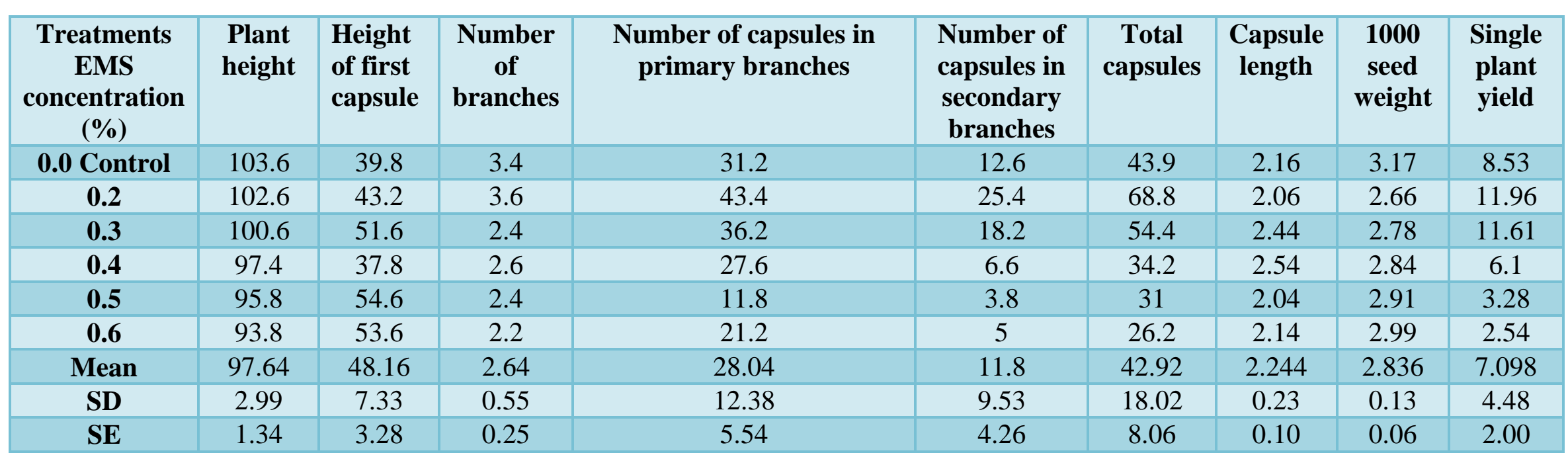


However other characters viz., number of branches, number of capsules per primary branches, number of capsules per secondary branches and total number of capsules did not show dose specific linear relationship though EMS considerably affected these traits. In the case of VRI 3, dose specific reduction effect was found in plant height, total number of capsules and single plant yield. Similar results were reported by Kumar and Yadav. (2010).

Interestingly 1000 seed weight showed dose dependent positive linear relationship with EMS. This result was similar to the result obtained Sadashiv et al., (2012). All other traits viz., height of first capsule, number of branches per plant, number of capsules in primary branches, number of capsules in secondary branches and capsule length were considerably affected by EMS in nonlinear fashion.

\section{References}

Ariraman M, Gnanamurthy S, Dhanavelb D, Bharathi T andMuruga S 2014. Mutagenic effecton seed germination, seedling growth and seedling survival of Pigeon pea (Cajanus cajan (L.) Millsp). International Letters of Natural Sciences.21: 41-49.

JoshiA B 1961. Sesamum. Indian Central Oilseed Committee: 109.

Kochhar S L 2011. Economic botany in the tropics. Macmillan publishers India ltd. 172-174.

Kumar G, Pandey A 2018. Ethyl methane sulphonate induced changes in cyto- morphological and biochemical aspects of Coriandrum sativum L. Journal of the Saudi Society of Agricultural Sciences.18:469-475.

Kumar G, Yadav R S 2010. EMS induced genomic disorders in sesame (Sesamum indicum L.). Romanian journal of biology-plant biology. 55(2): 97-104.

Kumari V, Chaudhary H K, Prasad R, Kumar A, Singh A,Jambhulkar $S$ and Sanju $S$ 2016. Effect of Mutagenesis on Germination, Growth and Fertility in Sesame (Sesamum indicumL.). Annual Research \& Review in Biology. 10(6): 1-9.

Nayar N M and MehraK L 1970. Economic Botany.24 (1): 20-31.

Sadashiv B N, Vikram BD and Konddiram D $\mathrm{N}$ 2012. Effect of mutagens on seed germination, plant survival and quantitative characters of horsegram (Macrotyloma uniflorum (LAM) VERDC). International journal of life science and pharma research.2 (4): 129-136.

Scott S, Jones R and Williams W 1984. Review of data analysis methods for seed germination. Crop Science.24: 1192-1199.

Spencer-Lopes M, Forster B P and Jankuloski L(2018). Manual on mutation breeding: Food and Agriculture Organization of the United Nations (FAO). 78.

Yoshida S,Forno D A and Cock J H 1971. Laboratory manual for physiological studies of rice. Laboratory manual for physiological studies of rice.

\section{How to cite this article:}

Sandhiya. V., C. Parameswari, M. Kumar, C. Vanniarajan, N. Kumaravadivel, N. Sakthivel and Anand M. Badigannavar. 2020. Somatic Effects of Ethyl Methane Sulphonate on White Seeded Sesame (Sesamum indicum. L) Varieties. Int.J.Curr.Microbiol.App.Sci. 9(06): 2035-2040. doi: https://doi.org/10.20546/ijcmas.2020.906.250 